\title{
自己卑下的自己提示戦略に関する日米比較研究： 文化的信念とエラーマネージメント
}

橋本 博文

(北海道大学大学院文学研究科, 日本学術振興会特別研究員 DC) キーワード: 文化的信念, 自己卑下, エラーマネージメント

A comparison of self-effacement strategies in the US and Japan: Cultural beliefs and the logic of error management Hirofumi HASHIMOTO

(Graduate School of Letters, Hokkaido University, The Japan Society for the Promotion of Science research fellow DC) Key words: cultural beliefs, self-effacing, error management

\section{目 的}

日本人に特有とされる自己卑下的な自己提示は, 集団主義的社 会を生きる人々に“デフォルト”で採用されるエラーマネージメント 戦略として解釈可能である(橋本・山岸, 2008; 鈴木・山岸, 2004)。本研究の目的は, このエラーマネージメント戦略の背後に あると考えられる文化的信念の差異に着目することにより, 上述の 解釈を一歩進めることにある。山岸ら (Yamagishi, Hashimoto \& Schug, 2008)の研究では, 集団主義的な社会, 寸なわち自分の 属する集団から離脱する, あるいは排除されることが致命的な帰 結を招くような閉鎖的社会を生きる人々が採用するデフォルトの 戦略(適切な戦略を採用寸ることができない, あるいは適切な戦 略を採用するにはコストがかかり寸ぎる場合に採用される戦略)に は, 集団からの排除につながるエラー(たとえば, 他の人たちの感 情を損ねてしまうようなエラー)を減らすかたちでバイアスがかけら れていることを想定している。鈴木・山岸 $(2004)$ が実施した実験 室実験の結果は, デフォルトのエラーマネージメント戦略として自 己卑下的な自己提示を捉える解釈を支持するものであり，1）日本 人の自己卑下的な自己提示は, 状況の定義(より具体的には, 「総合認知能力テスト」と称するテストでの自身の成績を判断する 理由)が不明確な場合にのみ観察されること, そして, 2) 状況の 定義が明確になれば(自身の成績を判断する理由が現金のボー ナスを得るためであることがはっきりすれば), 自己卑下的な自己 提示は観察されなくなることを明らかにしている。鈴木・山岸 (2004)の研究では直接的な検証がなされていないが，日本人の 自己卑下的自己提示を上述の意味でのエラーマネージメント戦 略として捉える際には, 自己卑下的な振る舞いをする(あるいはし ない)場合に, 他者からどのような反応が返ってくるかの予測, な いしその予測を導く文化的信念が重要となり得る。本研究は, こ の意味での (自分の行動に対する) 他者の反応予測に焦点を当 て, その予測を生み出す信念の文化差を検討することを目的とし ている。

\section{方 法}

参加者 北海道大学の学生 176 名 (男性 115 名, 女性 61 名) ${ }^{1}$ お よびカリフォルニア大学サンタバーバラ校の学生 78 名 (男性 34 名, 女性 44 名) に協力を得た。

場面想定法質問紙 鈴木・山岸(2004)が実施した実験状況のシ ナリオ (総合認知能力テストと称するテストを受けた後, テスト結果 を知らされないまま, その成績を尋ねられる)を参加者に提示し, 1)この状況で自分の成績について尋ねられたとしたら, 同じ大学 の学生の成績と比べて「平均より上」だと回答するか, それとも「平 均より下」だと回答するかを尋ねた。そして 2)「平均より上」ないし 「平均より下」だと回答する人に対する印象と, 世間一般の人がそ れぞれに対して持つだろう印象をそれぞれ 9 点尺度で尋ねた。

${ }^{1}$ 日本人参加者のデータをもとにして得られた結果の一部は, 第 72 回日 本心理学会において報告されている。

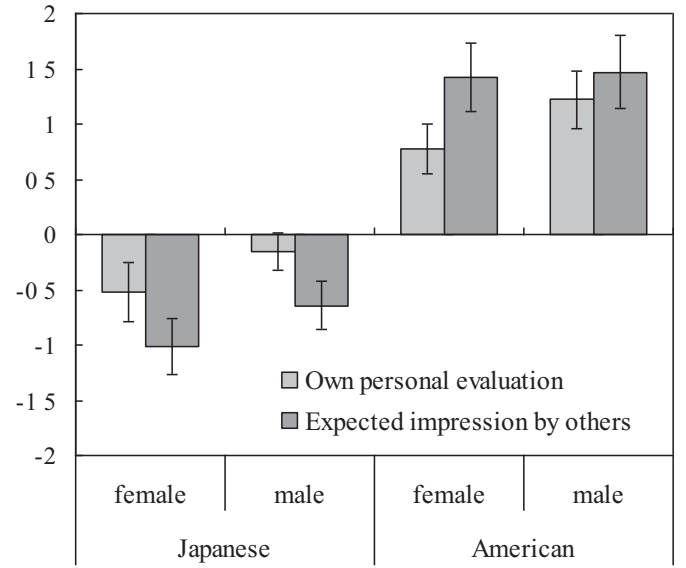

Figure1. Own personal evaluation and expected impression by others of those who answered either "below average" or "above average" by Japanese and American participants.

Note: -4 : have a better impression of those who answered "below average" to +4 : have a better impression of those who answered "above average"

\section{結 果}

日米において実施された質問紙研究の結果は, まず自己卑下傾 向の国籍差 (アメリカ人よりも日本人の方が自己卑下) と性差 (男 性よりも女性の方が自己卑下)を示していた。このことは, 橋本・山 岸 (2008)の結果と一貫する結果である。また,「平均より上」ない し「平均より下」だと回答する人に対して参加者自身が持つ印象と, 世間一般の人が持つだろう印象の予測に関する結果は, Figure 1 に示されるとおり, 日本人は自己卑下的に振る舞う人に対して, 反対にア訬力人は自己高揚的に振る舞う人に対して肯定的な印 象を持っていることを示していた。そして,この傾向は世間一般の 人からの印象予測において, より顕著になることも明らかにされた。 さらに、補足的に加えていたその他の印象評定項目の結果から, 日本人はア归力人と比較して, 自己卑下的に振る舞う人を“社会 的に賢い”と評価していることが示された。

\section{考 察}

自己卑下的な自己提示をデフォルトのエラーマネージメント戦略 として捉えた場合, エラーマネージメント戦略に見られる文化差 (あるいは性差)の背後には, 自己卑下的に振る舞わないことによ って生じるコスト(すなわち結果の重大さ)の差異, またそのコスト に対する信念体系の差異が存在すると考えられる。本研究の結 果は, 自己卑下的な振る舞いに対する信念体系の文化差が戦略 の文化差と対応していることを示唆していた。信念体系の性差に 関しては, 今後の検討が必要である。

\section{引用文献}

橋本博文・山岸俊男 (2008) 自己卑下的自己提示における性差の検討第 72 回日本心理学会／ 鈴木直人・山岸俊男 (2004) 日本人の自己卑下と自己高揚に関する実験研究 社会心理学研究, 20, 17-25 / Yamagishi, T, Hashimoto, H, \& Schug, J (2008) Preference vs strategies as explanations for culture-specific behavior Psychological Science, 19, 579-584 